\title{
The Assessment of Using the Sewage Sludge in Agriculture in Romania
}

\begin{abstract}
CARMELIA MARIANA DRAGOMIR BALANICA', AUREL GABRIEL SIMIONESCU², IULIAN GABRIEL BIRSAN, CEZAR IONUT BICHESCU' ${ }^{1}$ CRISTIAN MUNTENITA ${ }^{1 *}$

'Dunarea de J os University of Galati, 47 Domneasca Str., 800008, Galati, Romania

${ }^{2}$ Constantin Brancoveanu University of Pitesti, Faculty of Management Marketing in Economic Business, 1 Targul din Vale, 110040, Pitesti, Romania

Sewage sludge resulted from urban wastewater treatment plants is generally accepted as a valuable source of nutrient and soil conditioner for agricultural usage. Analysis of amount of heavy metals in sewage sludge is essential previous to utilization of the sludge to agriculture considering the inevitable risk of heavy metal toxicity to soil, vegetation and humans. The present paper aims to analyse the characteristics of the sewage sludge resulted in an urban area for 5 years. Sewage sludge generated from five wastewater treatment plants in the South and South Est part of Romania were analysed.
\end{abstract}

Keywords: Sewage sludge; Soil fertilizer; human health

Technological advances, increasing incomes and improving living standards have the immediate effect of increasing resource use and implicitly, pollution [1]. Like circumstances has conducted to an increase in the cases of usage of heavy metals. Annually there is a significant increase of heavy metals reused and included into products. These heavy metals are noxious to human health and the environment at certain level of concentrations, that is a important cause of concern [2].

By December 31, 2018, Romania has to fully comply with European Union Directive 91/271/EEC, which means that all agglomerations with a population greater than 2000 p.e will be served by the sewage treatment plant and, implicitly, sludge will occur [3]. Approximately $80 \%$ of Romania's cities have a combined sewerage system (domestic wastewater and rainwater). Industrial waste water has also a significant importance in the final flow to the treatment plant and consequently the industrial waste water discharges may significantly influence the quality of the sludge [4]. After the water treatment process there are two categories of substance fractions: liquid - water and solid - liquid - sludge. Sludge is, in fact, the waste of the treatment plant and EC proposals for $50 \%$ reduction of waste up to 2050 include this type of by-product [5-7].

In order to keep the risks to public health to a minimum, the water treatment planthas to regularly supply effective, different barriers to contaminants [8-9]. Hazard evaluations and controls aimed primarily to create safe systems.

The recovery and re-use of secondary products considered as waste is a growing priority in urban life. Moreover, this area faces various socio-economic, environmental and health challenges [10]. Wastewater and sewage sludge are a notable source of water, soil and air pollution and are a risk of spreading infectious diseases. Sewage sludge is the residual of wastewater treatment. The quantity of sludge produced per inhabitant rely upon numerous factors and thus is absolutely variable [11]. The structure of this sludge must be analysed rigorously since it can be rich in nutrients, however frequently loaded with significant concentrations of pollutants firstly heavy metals, and therefore countries look for different methods for its disposal [12]. The Sewage Sludge Directive (86/278/EEC) reviewed in 2000, mainly aims to establish the use of sewage sludge in agriculture so that to prevent noxious effects on soil, vegetation, animals, human health butalso supporting its correct usage [13].

Considering that, special preparatory measures should be achieved to establish that population, flora and fauna and the environment are absolutely protected against the damaging effects arising from the unrestrained application of sludge [14-16].

Withal should be considered that sewage sludge can have important agronomic characteristics and it is consequently justified to promote its utilization in agriculture provided it is applied properly [17-19]. Considering that the application of sewage sludge should not deteriorate the quality of the soil and of agricultural crops. The utilization of sludge must be restricted or even restricted when the concentration of heavy metals in the soil exceeds the limit values since may be toxic to agricultural products and also to population [20-21].

The aim of the present paper is to propose a feasible solution covering economic perspectives in order to accomplish an achievable solution.

\section{Experimental part}

Starting with 2011 in the south and south-east regions of Romania have been set up waste water treatment plants. The five counties: Giurgiu, Calarasi, Braila, Galati and Tulcea have more than 1.6 million of inhabitants and are generally predominant agricultural areas.

The wastewater treatment plants have two main processes: wastewater treatment process and sludge treatment process. The general wastewater treatment scheme is shown in figure 1 .

The wastewater treatment system consists of mechanical and biological treatment. In the mechanical treatment solids parts are removed by bar screens and grit by sedimentation. Biological treatment is applied to remove biodegradable organic pollutants from water that can feed for microorganisms and elimination of organic substances dissolved in water is done by absorbing them to the surface of cells, microorganisms, in the main bacteria. As a result, new bacterial cells and so-called metabolites appear.

The determination of iron, zinc and manganese metals was done by flame atomic adsorption spectrophotometric methods, based on the standard SR ISO 8288:2001 for $\mathrm{Cr}$, $\mathrm{Cu}, \mathrm{Cd}, \mathrm{Co}, \mathrm{Ni}$, and $\mathrm{Zn}[22]$. 


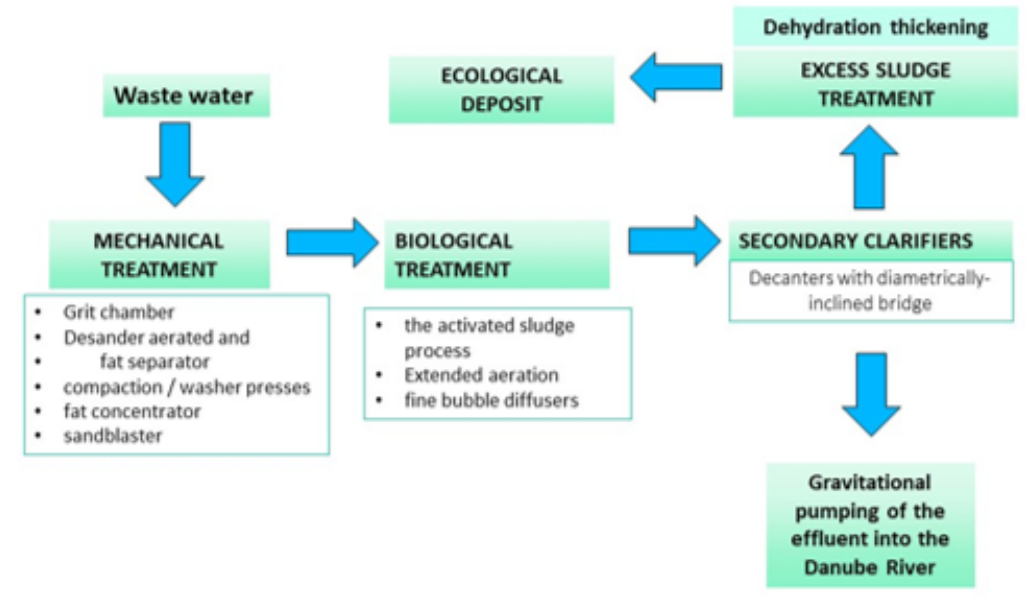

Fig. 1 The general wastewater treatment scheme

As a basic principle, nebulization was performed in the flame of the atomic absorption spectrometer of the filtered and acidified (or diluted) sample. Direct determination of the concentration of each element was made according to the specific absorbance of each one using a spectrometer equipped with a continuous background correction system. All reagents were of recognized analytical quality, so their use did not affect the accuracy of the determination. Deionized or distilled water used and do not have a metal content in the control sample detected by concentrations:

Nitrogenic acid, $p=1.4 \mathrm{~g} / \mathrm{mL}$;

Nitrogenic acid, $\mathrm{C}\left(\mathrm{HNO}_{3}\right) \sim 1.5 \mathrm{~mol} / \mathrm{L}$;

$100 \mathrm{~mL}$ of nitric acid was added to $600 \mathrm{~mL}$ of water and diluted to $1000 \mathrm{~mL}$;

Nitric acid, c ( $\left.\mathrm{HNO}_{3}\right) * 0.03 \mathrm{~mol} / \mathrm{L}$;

$1 \mathrm{~mL}$ of concentrated nitric acid was added to $400 \mathrm{~mL}$ of water and diluted to $500 \mathrm{~mL}$ with water;

Metals, standard metal solutions of $1000 \mathrm{~g} / \mathrm{L}$.

For each of the elements to be determined, $1000 \mathrm{~g}$ of pure metal was weighed and dissolved in nitric acid, heating until complete dissolution. It was left to cool and the solution was transferred quantitatively to a $1000 \mathrm{~mL}$ volumetric flask, brought to the mark and homogenized. Each of the standard solutions was stored in polyethylene containers. $1 \mathrm{~mL}$ of each of these standard solutions contains $1.00 \mathrm{mg}$ of metal.

As the equipment was used for atomic absorption spectrometer equipped with the appropriate metal hollow cathode lamps to determine a correction device that allowed the non-specific absorbance and a set nebulizerburner for the air-acetylene flame.

Analysis of $\mathrm{Cu}, \mathrm{Cr}, \mathrm{CO}, \mathrm{Ni}$ and $\mathrm{Cd}$ was done by calibration curves using the AAW inLab soft belonging to Perkin Elmer atomic adsorption spectrophotometer based on these standards: SR ISO 9174:1998 for Cr, SR EN ISO 5961:2002 for Cd, SR EN ISO 15586:2004 for trace elements ( $\mathrm{Cu}, \mathrm{Pb}$ and $\mathrm{Ni}$ ).

\section{Results and discussions}

The sewage sludge used in this article was achieved from urban wastewater treatment collected from the WWTP of Giurgiu, Calarasi, Braila, Galati and Tulcea.The presence of heavy metals in municipal sludge was analyzed for 5 years, from 2013 to 2017. Should be noted that the urban wastewater has chemical and biological factors have values below the limit imposed by legislation.

The results indicate that the heavy metals $\mathrm{Cr}, \mathrm{Cu}, \mathrm{Cd}, \mathrm{Co}$, $\mathrm{Ni}$, and $\mathrm{Zn}$, were present in the sewage sludge and their concentrations were variable, but far below the legislative limits. Figure 2 shows the evolution of the heavy metal quantities studied in this paper, depending on the limit values imposed (presented with red interrupted line).

The chromium concentrations $(\mathrm{Cr})$ in the Giurgiu and Calarasi areas register slightly increases during the analysed period comparing with the other three counties. The highest values were those in 2016 respectively $77 \mathrm{mg} /$ $\mathrm{kgd}$. m. in Giurgiu and $76 \mathrm{mg} / \mathrm{kg} \mathrm{d}$. m. in Calarasi. In Braila $37.53 \mathrm{mg} / \mathrm{kg} \mathrm{d}$. $\mathrm{m}$. is the maximum value, registered in 2015 relatively comparable with Tulcea $31.25 \mathrm{mg} / \mathrm{kg} \mathrm{d}$. $\mathrm{m}$. from 2014.

The concentrations of copper ( $\mathrm{Cu}$ ) from all the study areas were very low and below the limit values. The $\mathrm{Cu}$ concentrations were in the range $10.50 \mathrm{mg} / \mathrm{kg} \mathrm{d} . \mathrm{m}$. to $248.00 \mathrm{mg} / \mathrm{kg} \mathrm{d}$. $\mathrm{m}$. The Giurgiu municipality had the highest concentration of $\mathrm{Cu}$. The argument for the higher Cu concentrations could have been caused possible by the corrosion of the water supply pipes, whose composition includes copper. Another explanation for the high levels of $\mathrm{Cu}$ in sludge can be the use of copper scrubbers as abrasives in general cleaning in housekeeping.

For the Cadmium ( $\mathrm{Cd}$ ) there are minor differences among the considered zones. The Cadmium values were in the range of $0.10 \mathrm{mg} / \mathrm{kg} \mathrm{d}$. m. Braila to $1.95 \mathrm{mg} / \mathrm{kg} \mathrm{d}$. m. Giurgiu in 2015. The five-year average of the area analysed was $0.81 \mathrm{mg} / \mathrm{kg} \mathrm{d}$. m. comparing to $10 \mathrm{mg} / \mathrm{kg} \mathrm{d}$. m. the maximum limit values. The major sources in urban wastewater and sewage sludge results from diffuse sources like food products, detergents and storm water.

The cobalt ( $\mathrm{Co}$ ) concentrations in the investigated area do not point out a major change of sewage sludge. Higher cobalt concentrations are registered in Braila $7.2 \mathrm{mg} / \mathrm{kg} \mathrm{d}$. $\mathrm{m}$. the five years average comparing to $50 \mathrm{mg} / \mathrm{kg} \mathrm{d}$. $\mathrm{m}$. the permitted concentrations.

An increase in the concentrations of nickel ( $\mathrm{Ni}$ ) may be observed in Calarasi and Giurgiu from 2013 to 2016. In these areas the values range from 19.4 to $76.00 \mathrm{mg} / \mathrm{kg} \mathrm{d}$. $\mathrm{m}$. In Tulcea county the values are relatively constant $13.68 \mathrm{mg} / \mathrm{kg} \mathrm{d}$. $\mathrm{m}$. the five years average. The watersoluble salts of nickel are a significant issue of contamination in aquatic systems. Zinc results in wastewaters from the plating and metal processing industries.

The concentrations of zinc ( $Z n)$ from all the study counties were higher in Giurgiu and Calarasi and below the guideline values. The source of $\mathrm{Zn}$ in the sewage sludge may be due to the use of different domestic cleaning material. Likewise, $\mathrm{Zn}$ is a component of galvanized steel including water distribution pipes and the circumstance is that its presence may be due to corrosion and the metal may find to the WWTPs. 


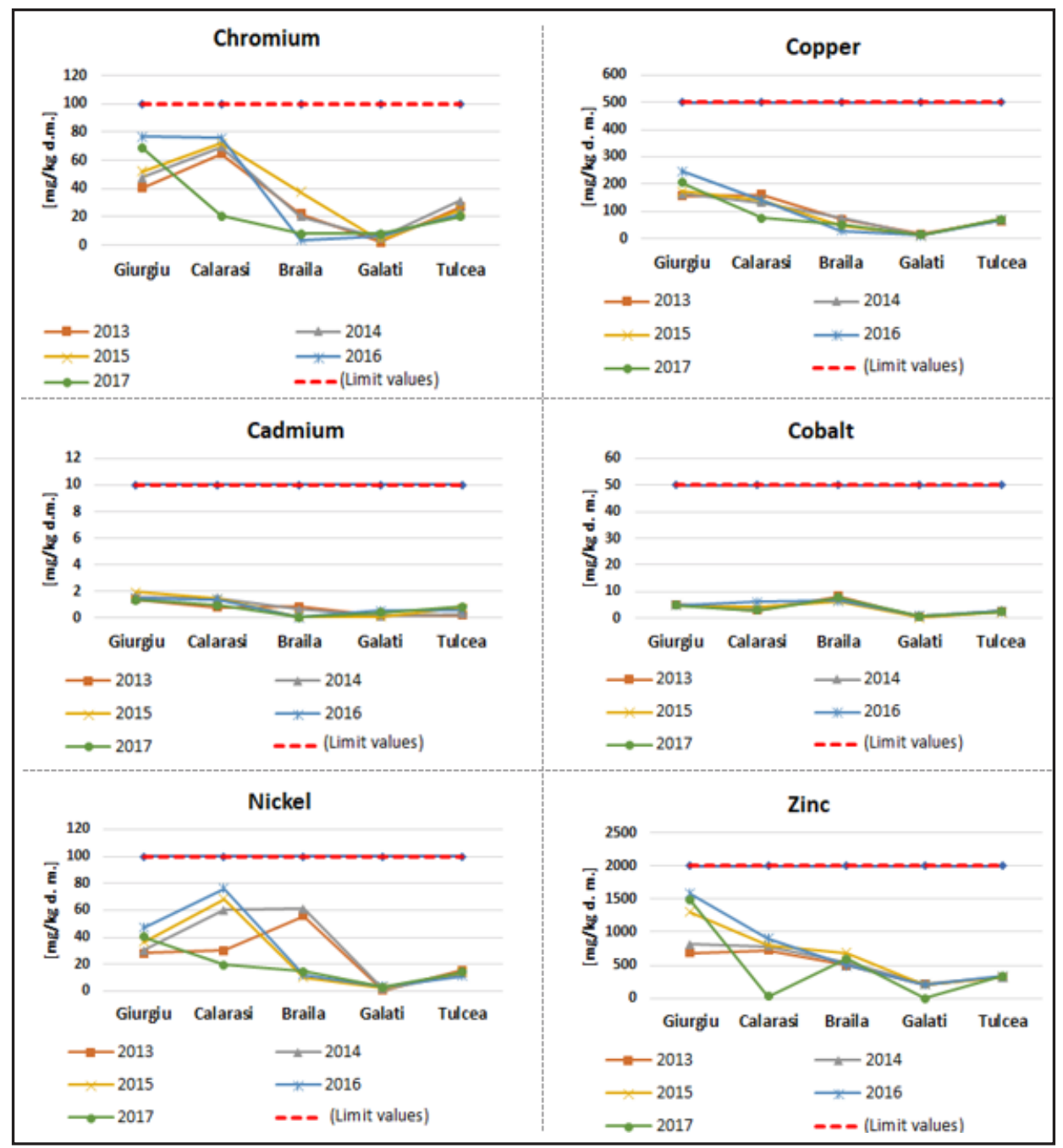

Fig. 2. Contents of sludge from wastewater treatment plants for 2013-2017

For all the five investigated areas, the water $\mathrm{pH}$ for the period 2013-2017 was less than 7. The total metal concentrations existing in sewage sludge samples taken from the five waste water treatment plants in Romania indicated a range of fluctuation analogously with the characteristics of the wastewater generated from the respective municipalities and the level of industrial settlements existing in the area.

\section{Conclusions}

In all the WWTPs the heavy metals concentrations were below the limitvalues. The presence of heavy metals might be perilous to the environment and the sludge should be used for agricultural fields taking into account the potential of the heavy metals accumulates in the soil.

Sludge is officially classified as waste, but according to the waste management hierarchy, it is acceptable to use the sludge beneficially whenever feasible, as an organic fertilizer on land, or as a source of energy recovered by combustion. In accordance with national and EU policy, sludge should be used with the most practical and efficient means so as to avoid as much as possible the disposal of sludge in landfills. Is compulsory to check the quality of sludges and of the soils on which they are applied and therefore to analyse and to inform the users. Likewise, it is essential to limit the quantity of heavy metals supplementary used to cultivated soil by setting maximum accumulation for the quantities of sludge used yearly and ensuring that the limit values for the concentration of heavy metals in the sludge used are not overrun. It is recommended, on certain conditions, the sludge to be

treated before being applied in agriculture in in order to avoid the risk to human.

There is growing general agreement that resource recovery and reuse can essentially protect human and environment health and encourage food security, cost recovery in the sanitation sector in urban areas.

\section{References}

1.BENNETT, L.E.; BURKHEAD, J.L.; HALE, K.L.; TERY, N.; PILON, M.; PILON-SMITS, E.A.H; J. Environ. Qual. 2003, 32, 432-440

2.JAISHANKAR, M.; TSETEN T.; ANBALAGAN, N.; MATHEW, B., B.; BEEREGOWDA, K., N.; Interdiscip Toxicol. 2014 Jun; 7(2): 60-72.

3.LAMASTRA, L.; SUCIU, N. A. ; TREVISAN, M. ; Chemical and Biological Technologies in Agriculture 2018 5:10

4.*** EC Directive. (1991), Directive concerning urban waste water treatment. Directive 91/271/CEC.

5.DOLGEN, D.; ALPASLAN, M., N.; DELEN N.,J Environ. Manage. 84(3), 2007, pp 274-281.

6.TIRUNEH, A., T.; FADIRAN, A., O.; MTSHALI, J., S.; International J ournal of Environmental Sciences, 2014 5, 197-216.

7.GAWDZIK, J. and GAW DIZIK, B. Pol. J. Environ. Stud., 2012, 21(6), pp 1603-1611.

8.SINGH, R.,P.; AGRAWAL, M., Waste management, 2008, 28, 347-358. 9.SCHIOPU, A.-M.; APOSTOL, I.; HODOREANU, M.; GAVRILESCU, M.; Environmental Engineering and Management Journal, 2007, 6, 451465.

10.NICOLAU, M., BUMBAC, C., DUMITRESCU, C., STOICA, L., J. Environ. Prot. Ecol, 9, no.3, 2008, p. 513

11.SONTHIPHAND, P., LIMPIYAKORN, T., Appl. Microbiol. Biotechnol., 89, no. 6, 2011, p.843

12.FIJALKOWSKI, K,; RORAT, A.; GROBELAK, A.; KACPRZAK, M., .; J Environ Manage. 2017, 203:1126-36. 
13.*** European Comission. European Commission Working Document on Sludge. Third Draft, Brussels 27 April 2000, DG Environment; 2000.http://ec.europa.eu/environment/waste/sludge/pdf/ sludge.en.pdf

14.*** EC Directive, (1986), Council Directive 86/278/EEC of 12 June 1986 on the protection of the environment, and in particular of the soil, when sewage sludge is used in agriculture.

15.MANEA, E.E., BUMBAC, C., TIRON, O., DINU, L.R., BADESCU, V.R., Rev. Chim. (Bucharest), 68, no. 8, 2017, p.1723

16.GHEORGHE, S., VASILE, G.G., STOICA, C., NITA-LAZAR, M., LUCACIU, I., BANCIU, A., Rev. Chim. (Bucharest), 67, no. 8, 2016, p. 1469

17.McGRATH, S.,P.; LANE, P., W.; Environ. Pollut. 60, 1989, pp 235-256
18.NAGAJYOTI, P., C.; LEE, K., D.; SREEKANTH, T., V., M.; Environ Chem Lett 8(3), 2010, 199-216.

19.DUMITRESCU, C., COCARTA, D., M.; BADEA, A.; Scientific Bulletin of Politehnica University Bucharest, 2012, Series D, 74, 217- 228.

20.ITICESCU, C., GEORGESCU L.P., GURAU, G., MURARESCU, M., DIMA, D., MURARIU G., GHEORGHIES, C.; Environmental Engineering and Management J ournal, 2015, 10, 2457-2463.

21.*** SR EN ISO 17294-2, 2005. The water quality. The application of the Inductively-Coupled Plasma Mass Spectrometry Method. Two partThe 62 elements determination. US EPA 3015 / 1994 - Microwave assisted acid digestion of aqueous samples and extracts

Manuscript received: 15.09 .2018 